\title{
Loss of Serotonin Transporter Protein after MDMA and Other Ring-Substituted Amphetamines
}

\author{
Tao Xie', Liqiong Tong', Michael W McLane', George Hatzidimitriou', Jie Yuan', Una McCann ${ }^{2}$ and \\ George Ricaurte*,I \\ 'Department of Neurology, Johns Hopkins University School of Medicine, Baltimore, MD, USA; ${ }^{2}$ Department of Psychiatry and Behavioral \\ Sciences, Johns Hopkins University School of Medicine, Baltimore, MD, USA
}

\begin{abstract}
We studied in vivo expression of the serotonin transporter (SERT) protein after 3,4-methylenedioxymethamphetamine (MDMA), p-chloroamphetamine (PCA), or fenfluramine (FEN) treatments, and compared the effects of substituted amphetamines to those of 5,7-dihydroxytryptamine (5,7-DHT), an established serotonin (5-HT) neurotoxin. All drug treatments produced lasting reductions in 5-HT, 5-HIAA, and $\left[{ }^{3} \mathrm{H}\right.$ ]paroxetine binding, but no significant change in the density of a $70 \mathrm{kDa}$ band initially thought to correspond to the SERT protein. Additional Western blot studies, however, showed that the $70 \mathrm{kDa}$ band did not correspond to the SERT protein, and that a diffuse band at $63-68 \mathrm{kDa}$, one that had the anticipated regional brain distribution of SERT protein (midbrain $>$ striatum > neocortex > cerebellum), was reduced after 5,7-DHT and was absent in SERT-null animals, was decreased after MDMA, PCA, or FEN treatments. In situ immunocytochemical (ICC) studies with the same two SERT antisera used in Western blot studies showed loss of SERT-immunoreactive (IR) axons after 5,7-DHT and MDMA treatments. In the same animals, tryptophan hydroxylase (TPH)-IR axon density was comparably reduced, indicating that serotonergic deficits after substituted amphetamines differ from those in SERT-null animals, which have normal TPH levels but, in the absence of SERT, develop apparent neuroadaptive changes in 5-HT metabolism. Together, these results suggest that lasting serotonergic deficits after MDMA and related drugs are unlikely to represent neuroadaptive metabolic responses to changes in SERT trafficking, and favor the view that substituted amphetamines have the potential to produce a distal axotomy of brain 5-HT neurons.
\end{abstract}

Neuropsychopharmacology (2006) 31, 2639-265I. doi:I0.1038/sj.npp. I30 I031; published online 25 January 2006

Keywords: MDMA; fenfluramine; p-chloroamphetamine; amphetamine; neurotoxicity

\section{INTRODUCTION}

Substituted amphetamines such as 3,4-methylenedioxymethamphetamine (MDMA), $p$-chloroamphetamine (PCA), and $N$-ethyl- $\alpha$-methyl-m-[trifluoromethyl] phenethylamine (fenfluramine, FEN) have the potential to produce lasting effects on brain serotonin (5-HT) neurons. In particular, after certain dosing conditions, MDMA (Green et al, 2003), PCA (Sanders-Bush and Steranka, 1978; Fuller, 1992), and FEN (Schuster et al, 1986; Appel et al, 1989, 1990; McCann et al, 1997) produce long-term reductions in the concentrations of 5-HT and its major metabolite, 5-hydroxyindoleacetic acid (5-HIAA), the activity of 5-HT's rate limiting synthetic enzyme, tryptophan hydroxylase (TPH), and the

\footnotetext{
*Correspondence: Dr GA Ricaurte, Department of Neurology, Johns Hopkins Medical Institutions, 5501 Hopkins Bayview Circle, Room 5B.7IE, Baltimore, MD 21224, USA, Tel: + I 410550 0993, Fax: + I 410550 2005, E-mail: Ricaurte@jhmi.edu

Received I September 2005; revised 26 October 2005; accepted 8 December 2005

Online publication: 23 December 2005 at http://www.acnp.org/ citations/Npp | 22305050547/default.pdf
}

abundance of membrane and vesicular 5-HT transporters, as measured by $\left[{ }^{3} \mathrm{H}\right]$ paroxetine and $\left[{ }^{3} \mathrm{H}\right] \mathrm{DTBZ}$ binding, respectively. In addition, tract-tracing studies after MDMA show reduced anterograde $\left[{ }^{3} \mathrm{H}\right]$ proline transport along ascending 5-HT axonal projections (Callahan et al, 2001). Collectively, these findings have been taken to indicate that MDMA and related drugs have the potential to produce a distal axotomy of brain 5-HT neurons (Battaglia et al, 1987; O'Hearn et al, 1988; Molliver et al, 1990; Fuller, 1992; Wilson et al, 1993; Gibb et al, 1994; Seiden and Sabol, 1996; Green et al, 2003; Gudelsky and Yamamoto, 2003; McCann and Ricaurte, 2004).

Several recent investigations, however, report that the serotonin transporter (SERT) protein, as measured by Western blot analysis, is not decreased after MDMA, PCA, or FEN treatments that produce substantial reductions in 5-HT and $\left[{ }^{3} \mathrm{H}\right]$ paroxetine binding (Rothman et al, 2003, 2004; Wang et al, 2004, 2005). Based upon these observations, these investigators have suggested that serotonergic deficits after substituted amphetamines represent neuroadaptive changes in 5-HT metabolism related to SERT sequestration (trafficking) rather than neurotoxicity. If 
correct, this hypothesis would have far reaching implications, as the neurotoxic potential of certain substituted amphetamines is widely recognized (see above), and there has been extensive human use of MDMA recreationally (Kalant, 2001) and FEN clinically (McCann et al, 1997).

The SERT is a key molecular target of MDMA and other ring-substituted amphetamines (Rudnick and Wall, 1992). As an integral membrane protein belonging to the $\mathrm{Na}^{+} / \mathrm{Cl}^{-}$dependent transporter family (Amara and Kuhar, 1993), the SERT is chiefly responsible for terminating the action of 5-HT released into the synaptic cleft (Blakely et al, 1991; Hoffman et al, 1991; Rudnick and Wall, 1992). Molecular studies indicate that the SERT consists of 630 amino acids, has 12 transmembrane domains, and that its C- and Nterminal regions lie in the cytoplasm (Tate and Blakely, 1994; Qian et al, 1995). In recent years, it has become apparent that surface expression of the SERT on the cell membrane is amenable to regulation through various mechanisms (Qian et al, 1997; Quick, 2003; Samuvel et al, 2005), including rapidly modulated trafficking-dependent pathways susceptible to actions of amphetamines (Ramamoorthy and Blakely, 1999; Whitworth et al, 2002). For instance, studies using isolated cell systems indicate that both acute (Ramamoorthy and Blakely, 1999) and chronic (Whitworth et al, 2002) MDMA treatments increase SERT surface expression.

The purpose of the present studies was to further evaluate lasting effects of MDMA and other substituted amphet amines on SERT protein expression and other markers of brain 5-HT neurons, and compare their effects to those of 5,7-dihydroxytryptamine (5,7-DHT), an established 5-HT neurotoxin (Jonsson, 1980; Baumgarten and Lachenmayer, 2004). Specifically, using two different anti-SERT polysera, we sought to establish the validity and sensitivity of Western blot methods for detecting drug-induced changes in SERT protein expression, and to test the hypothesis that serotonergic deficits after substituted amphetamines represent neuroadaptive responses in 5-HT metabolism secondary to SERT sequestration (trafficking).

\section{MATERIALS AND METHODS}

\section{Drugs and Chemicals}

$( \pm)$ MDMA hydrochloride and $( \pm)$ FEN hydrochloride were obtained from the National Institute on Drug Abuse (Bethesda, MD); $( \pm)$ p-chloroamphetamine (PCA) hydrochloride was purchased from the Sigma Chemical Co. (St Louis, MO). SERT antibody 1, obtained from ImmunoStar (\#24330) (Hudson, WI), is a rabbit polyclonal antisera directed against a synthetic peptide sequence corresponding to amino acids 579-599 of the SERT. This antibody appears to be the same as that used by Rothman et al (2003) but obtained from Calbiochem (La Jolla, CA, now EMD Biosciences, San Diego, CA) instead of ImmunoStar (Hudson, WI; unpublished observations). SERT antibody 2, purchased from Santa Cruz Biotechnology (\#SC-1458) (Santa Cruz, CA), is a goat polyclonal antisera raised against a peptide fragment of the C-terminus of the SERT. The primary actin antibody was purchased from Sigma ( $\mathrm{St}$ Louis, MO) (\#A-5441) and a secondary antibody from Amersham (\#NA931 V). SDS-polyacrylamide gels (8 or
$10 \%$ ), PVDF membranes, $2 \times$ SDS Western loading buffer, and WesternBreeze chemiluminescent kit-anti-mouse/goat/ rabbit were purchased from Invitrogen (Carlsbad, CA). The ECL Western blotting analysis kit was purchased from Amersham Bioscience (Buckingshire, England). Igepal CA-630, sodium deoxycholate, PMSF, aprotinin, sodium orthovanadate, 5,7-dihydroxytryptamine (5,7DHT) creatine sulfate, pargyline hydrochloride, desipramine hydrochloride, and ascorbic acid were purchased from Sigma (St Louis, MO). $\left[{ }^{3} \mathrm{H}\right]$ paroxetine was purchased from PerkinElmer Life Sciences (Boston, MA). Citalopram was a generous gift from $\mathrm{H}$ Lundbeck (Copenhagen, Denmark). The protein DC assay kit was obtained from Bio-Rad Laboratories (Hercules, CA).

\section{Animals}

Male albino Sprague-Dawley rats weighing 290-310 g were purchased from Harlan (Indianapolis, IN). SERT-null mice and wild-type controls were kindly provided by Dr George Uhl, NIDA/IRP. Animals were individually housed and treated in clear acrylic cages in a temperature-controlled room $\left(21 \pm 1^{\circ} \mathrm{C}\right)$. All animal care and experimental manipulations were approved by the Institutional Animal Care and Use Committee at the Johns Hopkins University School of Medicine, and were in accordance with the National Institutes of Health Guide for the Care and Use of Laboratory Animals. The facility for housing and care of the animals was accredited by the American Association for the Assessment and Accreditation of Laboratory Animal Care.

\section{Drug Treatments}

Doses and regimens of drugs used in the present study were chosen based upon published reports demonstrating efficacy of these drug treatments in producing lasting effects on 5-HT neurons (including SERT binding).

5,7-DHT. Rats $(N=6-9$ per group) were treated $30 \mathrm{~min}$ before the start of the surgery with desipramine $(25 \mathrm{mg} / \mathrm{kg}$, i.p.) and pargyline $(50 \mathrm{mg} / \mathrm{kg}$, i.p.), in order to protect noradrenergic neurons from the neurotoxin and to prevent the degradation of 5,7-DHT. Rats were then anesthetized with sodium pentobarbital $(60 \mathrm{mg} / \mathrm{kg}$; i.p. $)$ prior to intraventricular (i.c.v.) injection of 5,7-DHT. 5,7-DHT was administered into the right lateral ventricle at a dose of 50,100 , or $150 \mu \mathrm{g}$ (dose calculated as the free base) in $7.5 \mu \mathrm{l}$ sterile $0.9 \%$ saline containing $1 \%$ ascorbic acid, delivered over 2 min using a $10 \mu \mathrm{l} \mathrm{Hamilton}$ syringe. Control animals received an equivalent volume of the vehicle. The dose of 5,7-DHT was selected based upon prior studies by Breese et al (1985). The stereotaxic coordinates of the injection site were $1.0 \mathrm{~mm}$ posterior from bregma, $1.5 \mathrm{~mm}$ lateral from the midline, and $3.5 \mathrm{~mm}$ deep from the dura using a stereotaxic atlas (Paxinos and Watson, 1998). $5,7-\mathrm{DHT}$ treatment was performed at room temperature $\left(21 \pm 1^{\circ} \mathrm{C}\right)$.

MDMA. Animals ( $N=6-8$ per group) were given MDMA orogastrically $(15 \mathrm{mg} / \mathrm{kg}$, every $1.5 \mathrm{~h} \times 3$, for a total dose of $45 \mathrm{mg} / \mathrm{kg}$ ), at an ambient temperature of $25 \pm 0.5^{\circ} \mathrm{C}$. Rats 
were placed at the warmer ambient temperature $1 \mathrm{~h}$ before the first dose of MDMA and maintained at that temperature for $3 \mathrm{~h}$ after the last dose of MDMA. Rats were then returned to a room at $21 \pm 1^{\circ} \mathrm{C}$. These particular treatment conditions were selected based on pilot studies in our laboratory showing that, under these conditions, MDMA produces large 5-HT deficits in the rat brain. Control animals received equal volumes of saline.

FEN. Animals (6-9 per group) were administered FEN intraperitoneally $(6 \mathrm{mg} / \mathrm{kg}$, every $2 \mathrm{~h} \times 4$, for a total dose of $24 \mathrm{mg} / \mathrm{kg}$ ) at $21 \pm 1^{\circ} \mathrm{C}$. Control animals received equal volumes of saline.

$P C A$. Animals (6-9 per group) received PCA intraperitoneally $(5 \mathrm{mg} / \mathrm{kg})$ at $21 \pm 1^{\circ} \mathrm{C}$. The dose of PCA was selected based on the paper of Rothman et al (2003). Control animals received equal volumes of saline.

\section{Dissection}

Brain regions were dissected free as previously detailed by Heffner et al (1980).

\section{Neurochemical Analyses}

At 1 week after drug treatment, regional brain concentrations of 5-HT and 5-HIAA were measured by means of highperformance liquid chromatography with electrochemical detection (HPLC-EC), as recently described (Ricaurte et al, 1992).

\section{SERT Binding}

At 1 week after drug treatment, quantitative measurement of $\left[{ }^{3} \mathrm{H}\right]$ paroxetine-labeled SERT was performed using the method of Battaglia et al (1987), with minor modification. Briefly, brain tissue was weighed and homogenized in 50

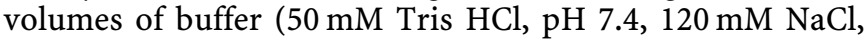
and $5 \mathrm{mM} \mathrm{KCl}$ ) with a Brinkman polytron homogenizer (setting \# 5, 30 s), and the homogenate was centrifuged in a Sorvall RC5B Plus centrifuge at 20000 r.p.m. (49 461g) for $10 \mathrm{~min}$. The resulting pellet was resuspended in 50 volumes of buffer, homogenized for $15 \mathrm{~s}$, and recentrifuged, as above. The final pellet was resuspended to wet tissue weight concentration of $12 \mathrm{mg} / \mathrm{ml}$ of buffer. Membrane suspensions were incubated with $\left[{ }^{3} \mathrm{H}\right]$ paroxetine at $21 \pm 1^{\circ} \mathrm{C}$ for $1 \mathrm{~h}$. $\left[{ }^{3} \mathrm{H}\right]$ paroxetine was used at a predetermined saturating concentration of $0.24 \mathrm{nM}$. Citalopram, at a final concentration of $1 \mu \mathrm{M}$, was used to estimate nonspecific binding. Incubations were terminated by rapid dilution with $5 \mathrm{ml}$ of ice-cold buffer, and immediate filtration through Whatman GFB filter. Membranes were harvested by filtration through Whatman GFB filters soaked in $0.05 \%$ polyethyleneimine. Filters were washed three times using $6 \mathrm{ml}$ of ice-cold buffer. Radioactivity was measured with a Packard-1500 Tricarb Liquid Scintillation Analyzer.

\section{Western Blot Analyses}

Dissected brain tissue was weighed, then homogenized (Brinkman polytron homogenizer, setting \#5, $30 \mathrm{~s}$ ) in RIPA buffer ( $4 \mathrm{ml}$ buffer per gram tissue) containing $1 \times \mathrm{PBS}, 1 \%$ Igepal CA-630, 0.5\% sodium deoxycholate, and $0.1 \%$ SDS, and proteinase inhibitors $(0.1 \mathrm{mg} / \mathrm{ml} \mathrm{PMSF}, 30 \mu \mathrm{l} / \mathrm{ml}$ aprotinin, and $1 \mathrm{mM}$ sodium orthovanadate). The homogenate was placed on ice for $30 \mathrm{~min}$ with intermittent shaking, then centrifuged in an Eppendorf 5415D centrifuge at 12000 r.p.m (11228g) for $15 \mathrm{~min}$. The supernatant was collected and centrifuged again, as above. The final resulting supernatant was stored at $-70^{\circ} \mathrm{C}$ until use. Protein content of the supernatant was determined using Bio-Rad DC/assay reagents, as per the manufacturer's instructions. Tissue samples were mixed (v/v: 1/1) with Invitrogen's $2 \times$ SDS loading buffer (62.5 mM Tris- $\mathrm{HCl}, \mathrm{pH} 6.8,10 \%$ glycerol, $2 \%$ SDS, $0.025 \%$ bromophenol blue, and $50 \mathrm{mM}$ dithiothreitol), heated to $90^{\circ} \mathrm{C}$ for $5 \mathrm{~min}$, and loaded on 8 or $10 \%$ Tris-glycine SDS-polyacrylamide gels, followed by electrophoresis and transfer onto $0.2 \mu \mathrm{m}$ PVDF membranes. After preincubation in $1 \times$ TBST plus $5 \%$ milk, membranes were incubated with SERT antibody 1 (1:330 dilution), SERT antibody 2 (1:200 dilution), or a mouse actin antibody (1:500 dilution) at room temperature for $2-4 \mathrm{~h}$. To visualize signals, an anti-rabbit chemiluminescent immunodetection kit from Invitrogen (Carlsbad, CA) was used for SERT antibody 1, and an ECL system from Amersham (Buckingshire, England) along with an anti-goat secondary antibody (SantaCruz \#SC2020) was used for SERT antibody 2. Equal protein loadings per lane $(200 \mu \mathrm{g})$ were calculated by prior protein determination, as above. Actin was used to further correct the loading amount in some studies. Band densities were semiquantitatively analyzed using either the $\mathrm{NIH}$ image program, Image J (http://rsb.info.nih.gov/ij/) or an MCID Elite 6.0 image analysis system (Amersham Biosciences Niagara Inc, St Catherines, Ontario, Canada).

\section{Immunocytochemical Studies}

Previously described methods were used (Hatzidimitriou et al, 1999), with slight modification. Briefly, rats $(N=3$ per group) were killed 1-2 weeks after treatment. Intracardiac perfusion was then performed under deep sodium pentobarbital anesthesia $(60 \mathrm{mg} / \mathrm{kg})$. After the vasculature was cleared with $150 \mathrm{ml}$ of ice-cold PBS, perfusion was continued with $400 \mathrm{ml}$ of cold $4 \%$ paraformaldehyde and $0.12 \%$ glutaraldehyde in $0.15 \mathrm{M}$ phosphate buffer, $\mathrm{pH} 7.4$. Tissue blocks were placed in buffered $4 \%$ paraformaldehyde for $4-6 \mathrm{~h}$ and then in $10 \%$ dimethylsulfoxide in PBS overnight. Blocks were frozen-sectioned $(30 \mu \mathrm{m})$ using a sliding microtome, and collected in cold PBS. Free-floating sections were preincubated in SuperBlock Blocking Buffer (Pierce, Rockford, IL) for $1 \mathrm{~h}$ at room temperature. Sections were then incubated at $4{ }^{\circ} \mathrm{C}$ for $90 \mathrm{~h}$ with SERT antisera 1 (diluted $1: 15000$ in SB/PBS $(1: 10)$ with $0.3 \%$ Triton X-100 and $5 \%$ normal goat serum), or SERT antisera 2 (diluted $1: 5000$ in SB/PBS $(1: 10)$ with $0.3 \%$ Triton X-100 and 5\% normal rabbit serum). Bound immunoglobulin was visualized with the Avidin/Biotin Peroxidase method using the Vectastain Elite rabbit and goat kits, respectively (Vector Laboratories, Burlingame, CA), and staining was enhanced with the osmiophilic reaction of Gerfen (1985). For tryptophan hydroxylase (TPH), immunocytochemistry was performed on tissue blocks cryoprotected in $0.1 \mathrm{M}$ phosphate buffer with $20 \%$ sucrose. Free-floating sections 
$(30 \mu \mathrm{m})$ were preincubated in PBS containing $0.5 \%$ gelatin, $2 \%$ normal rabbit serum, and $0.3 \%$ Triton $\mathrm{X}-100$ for $1 \mathrm{~h}$ at room temperature. Sections were then incubated at $4{ }^{\circ} \mathrm{C}$ for $48 \mathrm{~h}$ with TPH antiserum (diluted $1: 1000$ in PBS with $0.25 \%$ gelatin, $2 \%$ normal rabbit serum, and $0.3 \%$ Triton $\mathrm{X}-100$ ).
Secondary incubation extended overnight (approximately $20 \mathrm{~h}$ ) at $4{ }^{\circ} \mathrm{C}$ using the biotinylated anti-sheep reagent from the Vectastain Elite Sheep kit. The final incubation with avidin/biotin complex was carried out for $4.5 \mathrm{~h}$ at $4{ }^{\circ} \mathrm{C}$ and staining was enhanced as indicated above. a

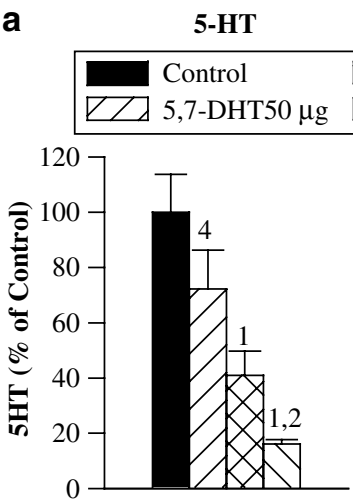

b

$\bowtie \varnothing$ 5,7-DHT100 $\mu \mathrm{g}$ $\triangle \backslash 5,7-D H T 150 \mu \mathrm{g}$

d

$70 \mathrm{kD}$ protein

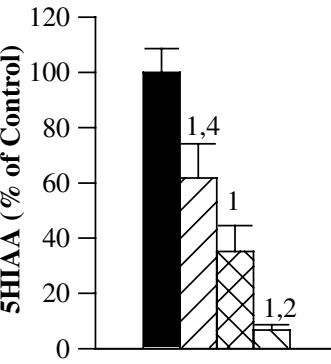
$\begin{array}{lllllllll}\mathrm{C} 1 & \mathrm{C} 2 & \mathrm{C} 3 & \mathrm{C} 4 & \mathrm{D} 1 & \mathrm{D} 2 & \mathrm{D} 3 & \mathrm{D} 4\end{array}$
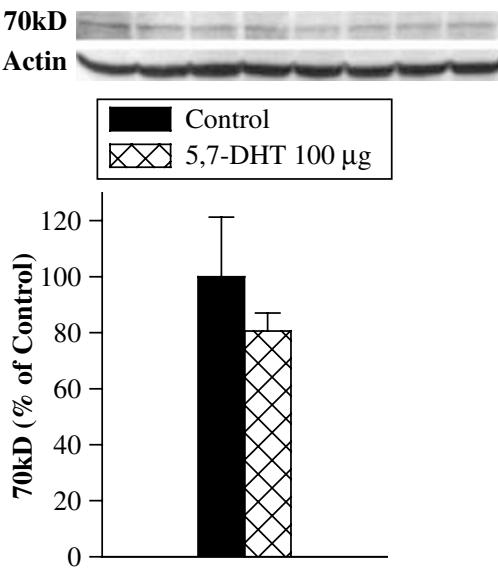

e $\begin{array}{llllllll}\mathrm{C} 1 & \mathrm{C} 2 & \mathrm{C} 3 & \mathrm{C} 4 & \mathrm{D} 1 & \mathrm{D} 2 & \mathrm{D} 3 & \mathrm{D} 4\end{array}$
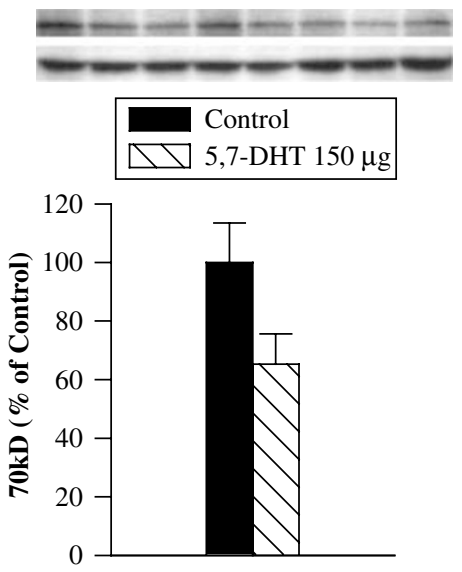

$\mathbf{f}$

Full Western blot - SERT antibody 1

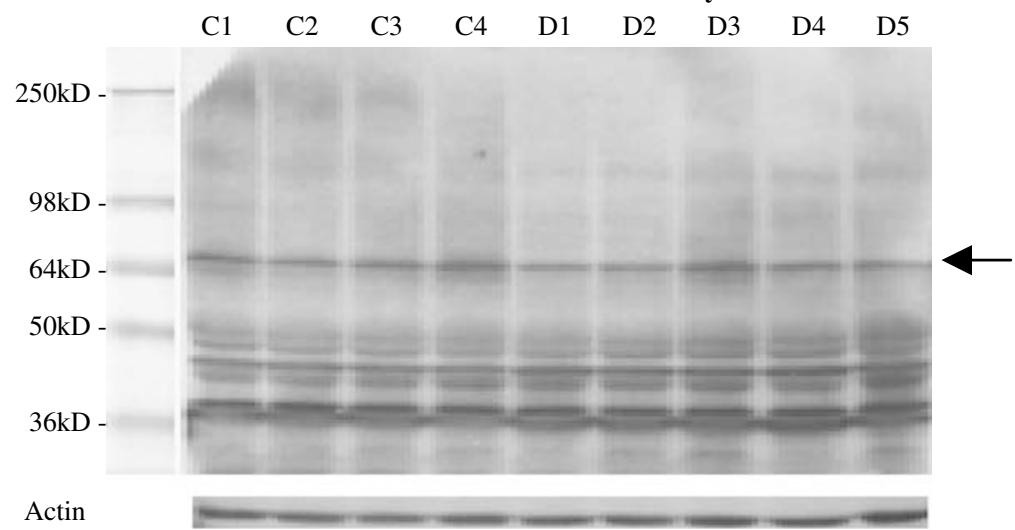

Figure I 5-HT (a), 5-HIAA (b), ${ }^{3} \mathrm{H}$ ]paroxetine binding (c), and $70 \mathrm{kDa}$ protein expression (d-f) in the cerebral cortex of rats treated with 5,7-DHT । week previously. After pretreatment with pargyline (50 mg/kg; i.p.) and DMI (25 mg/kg; i.p.), rats received vehicle or 5,7-DHT into the right lateral ventricle at a dose of 50, 100, or $150 \mu \mathrm{g}$ per rat ( $\mathrm{N}=6-9$ rats in each group), at ambient temperature of $21 \pm 1{ }^{\circ} \mathrm{C}$, and were killed I week after drug treatment. Control values for $5-\mathrm{HT}, 5-\mathrm{HIAA}$, and $\left[{ }^{3} \mathrm{H}\right]$ paroxetine binding were $0.38 \pm 0.05 \mu \mathrm{g} / \mathrm{g}, 0.16 \pm 0.01 \mu \mathrm{g} / \mathrm{g}$, and $2269 \pm 147 \mathrm{~d} . \mathrm{p} . \mathrm{m} . / \mathrm{mg}$, respectively. Bars represent the mean \pm SEM for each group. In all cases, statistically significant differences represent $p<0.05$. 'Different from control, ${ }^{2}$ different from $5,7-D H T 50 \mu g$, ${ }^{3}$ different from 5,7-DHT I00 $\mu \mathrm{g},{ }^{4}$ different from 5,7-DHT I $50 \mu \mathrm{g}$, *different from control. Differences in density of $70 \mathrm{kDa}$ band (arrow) in control and 5,7DHT-treated rats did not achieve significance (panels $d$ and e). Bottom panel (f) shows entire, representative Western blot prepared with SERT antibody I on a $10 \%$ minigel, as described in Materials and Methods. $\mathrm{C}=$ control; $\mathrm{D}=$ drug $(5,7-\mathrm{DHT})$. 


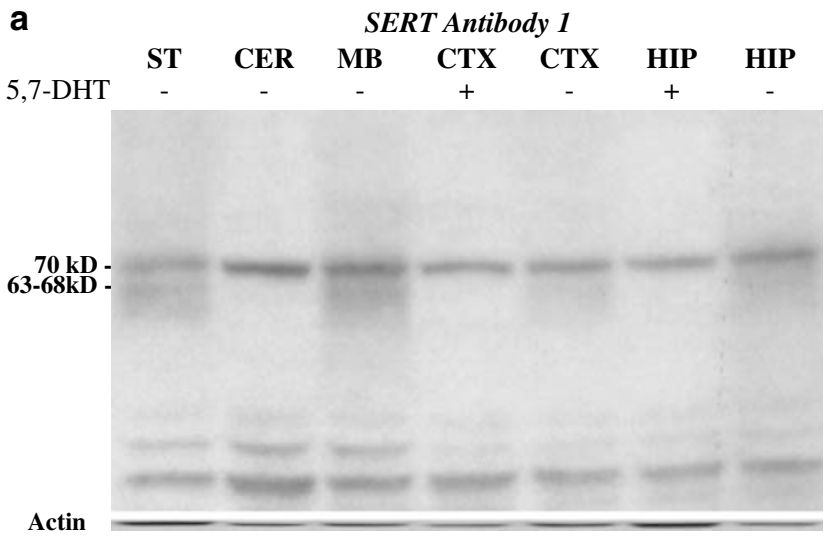

b

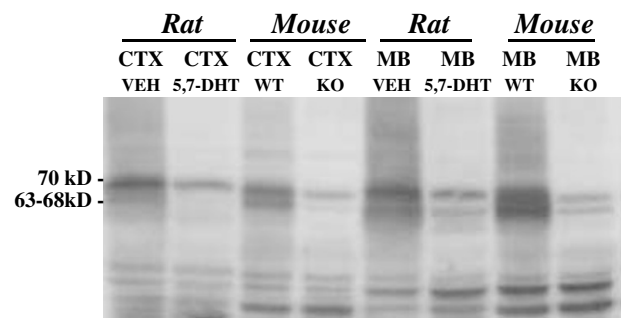

Figure 2 Top panel (a) shows Western blot prepared with SERT antibody I indicating that band at $70 \mathrm{kDa}$ has a relatively uniform density across various rat brain regions (ST, striatum; CER, cerebellum; MB, midbrain; CTX, cerebral cortex; HIP, hippocampus), and that it is not reduced I week after 5,7-DHT treatment (shown across top) in any of the brain regions examined. Note that a fainter, more diffuse band at approximately $63-68 \mathrm{kDa}$ has a density that is highest in the midbrain, lowest in the cerebellum, and intermediate in other regions examined. Also note that the density of the $63-68 \mathrm{kDa}$ band is markedly reduced I week after 5,7-DHT treatment. Western blot was prepared on an $8 \%$ minigel, as described in Materials and Methods. The same PVDF membrane was stripped and reblotted with actin antibody, showing loading amount of protein in each lane. Bottom panel (b) shows Western blot prepared with SERT antibody I on an $8 \%$ minigel using $200 \mu \mathrm{g}$ protein per lane from a 5,7DHT-treated animal (rat) and a SERT-KO animal (mouse). Note the marked decrease in abundance of 63-68 kDa band in 5,7-DHT-treated rat and in SERT-KO mouse, both in the parietal cortex (CTX) and midbrain (MB). Also note that band at approximately $70 \mathrm{kDa}$ is preserved in rat previously lesioned with 5,7-DHT, as well as in SERT-KO mouse. Minor species (rat vs mouse) and regional (cortex vs midbrain) differences are also evident.

\section{Statistical Analyses}

HPLC data were analyzed by one-way ANOVA, followed by Duncan's multiple range post hoc comparisons, when appropriate. Binding and Western blot data were analyzed by Student's $t$-test. Results were considered significant when $P<0.05$, using a two-tailed test. Data analyses were performed using the Statistical Program for the Social Sciences (SPSS for Windows, Release 10.5).

\section{RESULTS}

As anticipated, 5,7-DHT produced lasting, dose-related reductions of 5-HT, 5-HIAA, and $\left[{ }^{3} \mathrm{H}\right]$ paroxetine binding (Figure 1a-c). In contrast, in the same animals, 5,7-DHT failed to produce a significant reduction in the density of a $70 \mathrm{kDa}$ band thought to correspond to the SERT protein

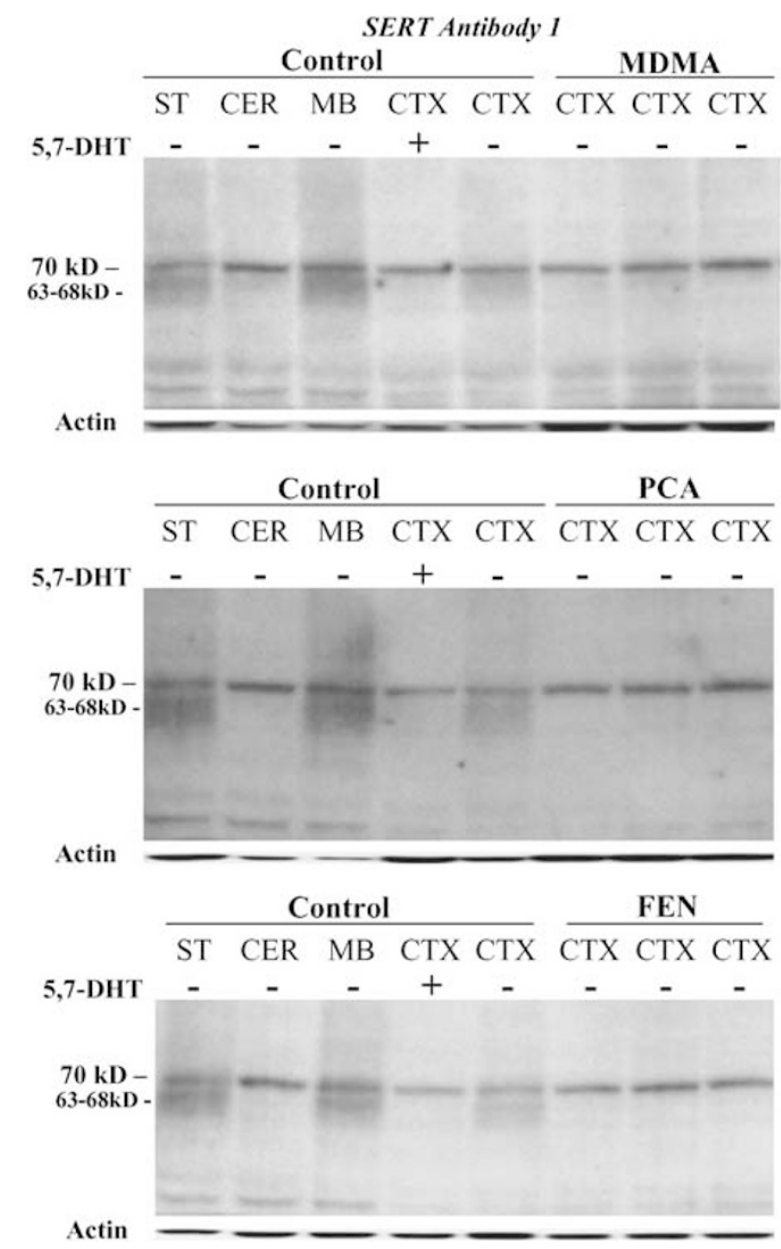

Figure 3 Western blots prepared with SERT antibody I showing reduced density of $63-68 \mathrm{kDa}$ band I week after treatment with MDMA (top panels), PCA (middle panels), or FEN (bottom panels). Rats were administered saline or MDMA $(15 \mathrm{mg} / \mathrm{kg}$, orally, every $1.5 \mathrm{~h} \times 3)$, PCA $(5 \mathrm{mg} / \mathrm{kg}$; i.p.), or FEN $(6 \mathrm{mg} / \mathrm{kg}$ every $2 \mathrm{~h} \times 4)$. Western blots were prepared on $8 \%$ minigels, as described in Materials and Methods. The same PVDF membranes were stripped and reblotted with actin antibody, showing comparable amounts of protein in each lane.

(Figure 1, panels d-f) (Rothman et al, 2003; Wang et al, 2005).

To test the possibility that the lack of a significant effect of 5,7-DHT in our studies might be related to 'signal to noise' issues (due to the large amount of SERT protein in platelets present in nonperfused brain tissue (Qian et al, 1995)), we removed all blood products by means of transcardial perfusion with $150 \mathrm{ml}$ of ice-cold PBS, then repeated our Western blot studies. As before, there was no significant reduction in the $70 \mathrm{kDa}$ band thought to correspond to the SERT protein (not shown).

To determine if the above-mentioned $70 \mathrm{kDa}$ band did, in fact, correspond to the SERT protein, we examined its relative regional brain distribution, and again evaluated its sensitivity to prior 5,7-DHT treatment. As shown in Figure 2, the $70 \mathrm{kDa}$ band does not exhibit the expected relative regional brain distribution of SERT, as it is equally abundant across brain regions, including the midbrain and cerebellum, which are known to differ vastly in SERT protein content (Qian et al, 1995). 

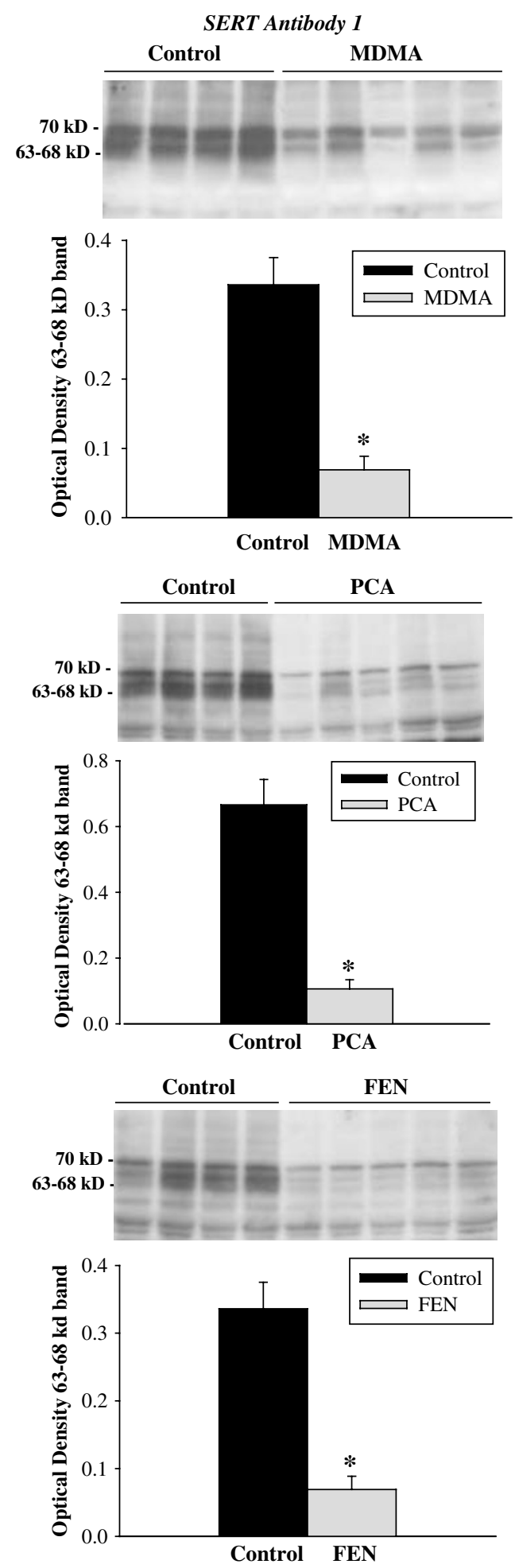

Figure 4 Quantitation of reduced density of 63-68 kDa band I week after treatment with MDMA (top panel), PCA (middle panel), or FEN (bottom panel). Results shown represent the mean \pm SEM for each group. Loading amount was maintained constant at $200 \mu \mathrm{g}$ of protein per lane. In all cases, statistically significant differences represent $p<0.05$; $C=$ control; $E=$ experimental. *Different from control.

In contrast to the $70 \mathrm{kDa}$ band that does not appear to correspond to the SERT protein (because it lacks the expected relative regional brain distribution and is not

reduced after 5,7-DHT), there is a nearby, more diffuse, 63$68 \mathrm{kDa}$ band that exhibits the relative regional brain distribution expected of the SERT (midbrain $>$ striatum $>$ hippocampus $>$ neocortex $>$ cerebellum) (Figure 2). This band is more readily discerned in $8 \%$ than in $10 \%$ polyacrylamide minigels (compare immunoblots in Figure 1 and Figure 2). Notably, the abundance of the $63-68 \mathrm{kDa}$ band is markedly reduced after 5,7-DHT treatment (Figure 2, upper and lower panels) and is absent in SERT-KO animals (Figure 2b). Also of note is the fact that SERT antibody 1 crossreacts with several other protein bands in SERT-null mice, including one at approximately $70 \mathrm{kDa}$.

Having identified a diffuse $63-68 \mathrm{kDa}$ band that, under the present conditions, appears to correspond to the SERT protein, we next examined if the density of this band was affected by prior treatment with substituted amphetamines (MDMA, PCA, or FEN). Like 5,7-DHT, all three substituted amphetamines produced reductions in the density of the 63-68 $\mathrm{kDa}$ band 1 week after treatment, with quantitative analyses showing significant decreases in the density of the 63-68 kDa band after MDMA, PCA, or FEN treatment (Figures 3 and 4). Reductions in SERT, as measured by Western blot analysis, were accompanied by reductions in 5-HT, 5-HIAA, and $\left[{ }^{3} \mathrm{H}\right]$ paroxetine binding (Figure 5).

To confirm our findings, we conducted additional Western blot studies using a second SERT antibody also raised against a C-terminus peptide of the SERT (see Materials and Methods). As before, we first carried out studies to identify which of the various bands visible on immunoblots using SERT antibody 2 had a regional brain distribution consistent with that of the SERT, then tested the effects of substituted amphetamines (MDMA, PCA, or FEN). Once again, a similar diffuse band at approximately $63-68 \mathrm{kDa}$ was evident; this band had the regional distribution expected of the SERT (midbrain $>$ striatum $>$ hippocampus $>$ neocortex $>$ cerebellum), was reduced by 5,7-DHT treatment, and was absent in SERT-null animals (Figure 6). As shown in Figure 7, the density of the 63$68 \mathrm{kDa}$ band was decreased 1 week after substituted amphetamine treatment. As with SERT antibody 1, quantitative studies with SERT antibody 2 showed significant decreases in the density of the 63-68 kDa band after MDMA, PCA, or FEN treatment (Figure 8).

Next, we examined SERT protein expression using an alternate, yet complementary, method. In particular, we used an in situ immunocytochemical (ICC) procedure that permits visualization of the SERT protein in brain sections. Using the same two SERT antibodies as in our Western blot studies, we observed clear reductions in the density of immunoreactive fibers that have the expected distribution and appearance of serotonergic fibers innervating the cerebral cortex (Figure 9) and hippocampal formation (Figure 10), both after 5,7-DHT (middle panels) and MDMA (lower panels) treatments.

As the SERT is a membrane protein amenable to cellular redistribution or trafficking (see Introduction), we also examined the expression of tryptophan hydroxylase (TPH), a cytoplasmic serotonergic protein not known to be modulated by trafficking-dependent pathways. In keeping with the SERT studies above, TPH-IR axon density was markedly reduced 1 week after treatment with 5,7-DHT or 

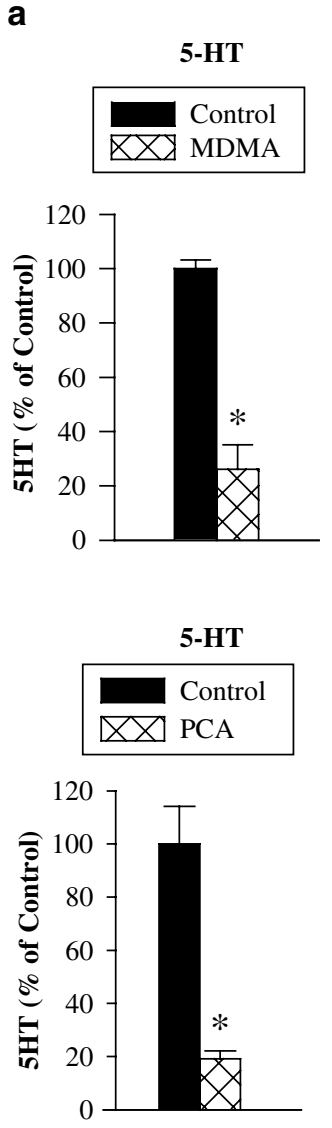

$5-\mathrm{HT}$
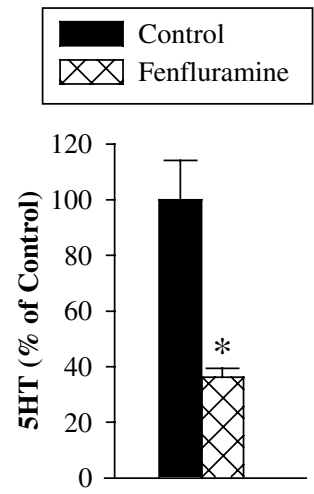

b

MDMA 5-HIAA

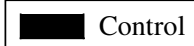
ХX MDMA

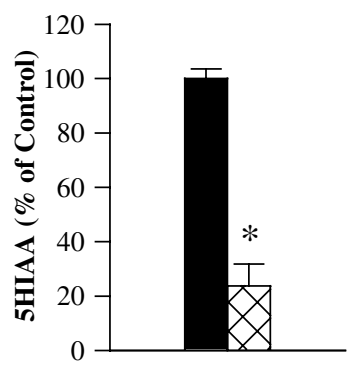

PCA

5-HIAA
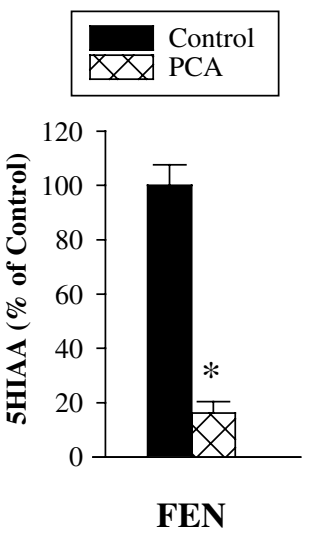

5-HIAA
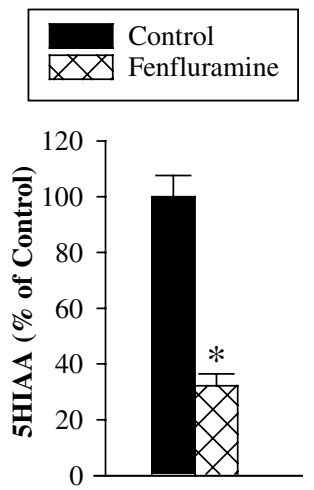

C

${ }^{3}$ H-Paroxetine binding

\begin{tabular}{|r|}
\hline Control \\
$\square \square \nabla$ MDMA \\
\hline
\end{tabular}

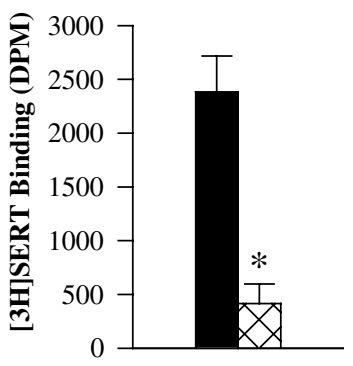

${ }^{3}$ H-Paroxetine binding
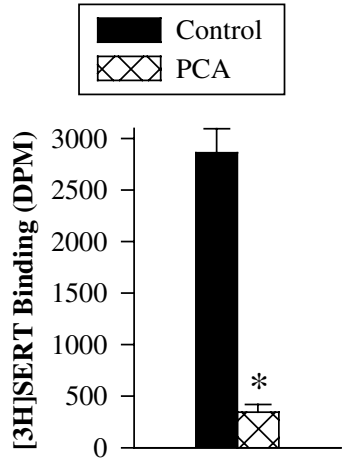

${ }^{3}$ H-Paroxetine binding
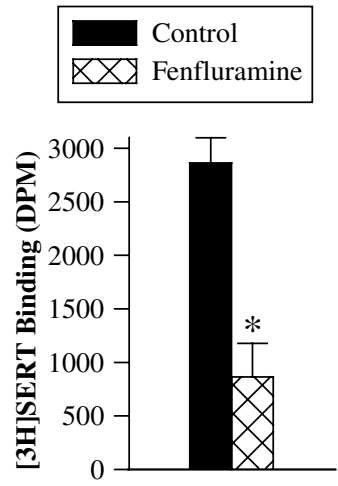

Figure 5 5-HT (a), 5-HIAA (b), and $\left[^{3} \mathrm{H}\right]$ paroxetine binding (c) in the cerebral cortex of rats treated with MDMA (upper panels), PCA (middle panels), or FEN (lower panels) I week previously, as detailed in Materials and Methods. For MDMA, control values for 5-HT, 5-HIAA, and [ $\left.{ }^{3} \mathrm{H}\right]$ paroxetine binding were $0.46 \pm 0.02 \mu \mathrm{g} / \mathrm{g}, 0.33 \pm 0.02 \mu \mathrm{g} / \mathrm{g}$, and $2383 \pm 334 \mathrm{~d} . \mathrm{p} . \mathrm{m} . / \mathrm{mg}$, respectively. For PCA, control values for 5-HT, 5-HIAA, and [ $\left.{ }^{3} \mathrm{H}\right]$ paroxetine binding were $0.26 \pm 0.03 \mu \mathrm{g} / \mathrm{g}, 021 \pm 0.02 \mu \mathrm{g} / \mathrm{g}$, and $2862 \pm 234 \mathrm{~d} . \mathrm{p} . \mathrm{m} . / \mathrm{mg}$, respectively; For FEN, control values for 5-HT, 5-HIAA, and [ $\left.{ }^{3} \mathrm{H}\right]$ paroxetine binding were $0.26 \pm 0.03 \mu \mathrm{g} / \mathrm{g}, 0.21 \pm 0.02 \mu \mathrm{g} / \mathrm{g}$, and $2862 \pm 234 \mathrm{~d} . \mathrm{m} . \mathrm{m} . \mathrm{mg}$, respectively. Results shown represent the mean \pm SEM for each group. In all cases, statistically significant differences represent $p<0.05$. *Different from control.

MDMA, again both in the cerebral cortex and hippocampal formation (Figure 11).

\section{DISCUSSION}

Recent results of Western blot studies have led some to reconsider the view that MDMA, PCA, and FEN have neurotoxic potential toward brain 5-HT neurons (Rothman et al, 2003, 2004; Wang et al, 2004, 2005). Specifically, based upon observations that substituted amphetamines produce decrements in 5-HT, 5-HIAA, and $\left[{ }^{3} \mathrm{H}\right]$ paroxetine binding without concomitantly decreasing the density of a band thought to correspond to the SERT protein, these investigators postulated that lasting serotonergic effects of MDMA and related drugs represent neuroadapative changes in 5-HT metabolism related to SERT sequestration ('trafficking'), rather than damage to 5-HT axon terminals. To 
SERT Antibody 2
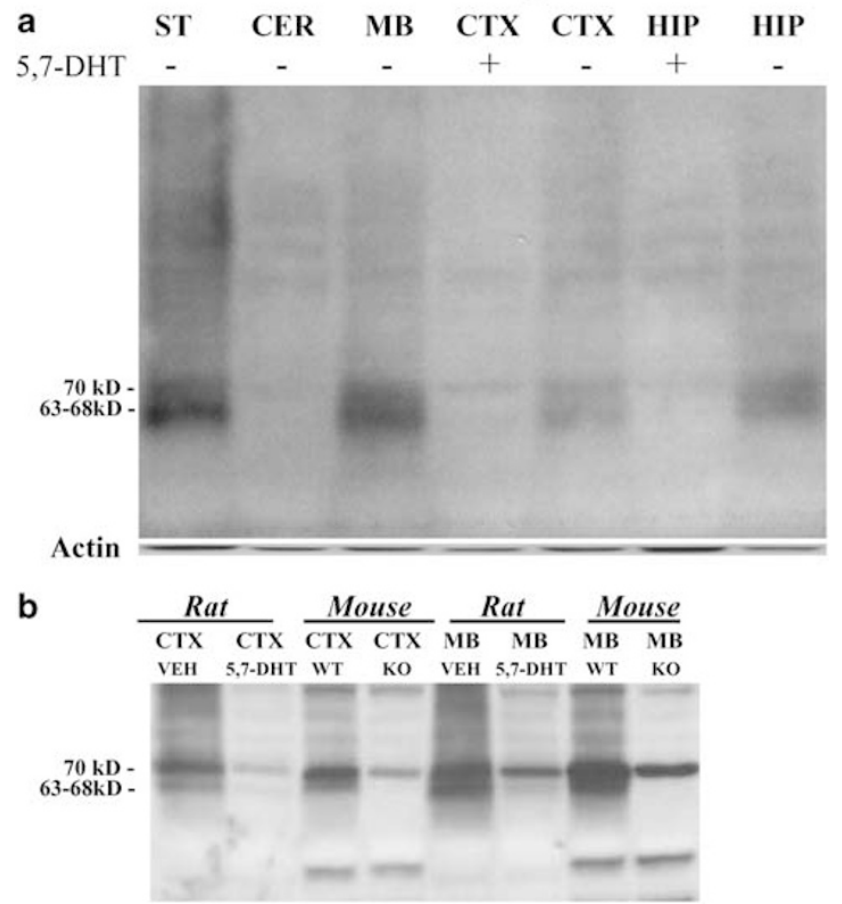

Figure 6 Top panel (a) shows Western blot prepared with SERT antibody 2 indicating that band at $63-68 \mathrm{kDa}$ has a density that is highest in the midbrain, lowest in the cerebellum, and intermediate in other brain regions (ST, striatum; CER, cerebellum; MB,- midbrain; CTX, cerebral cortex; HIP, hippocampus). Note reduced density of 63-68 kDa band week after 5,7-DHT treatment (shown across top) in all brain regions examined. Western blot was prepared on an $8 \%$ minigel using a total protein preparation, as described in Materials and Methods. The same PVDF membrane was stripped and reblotted with actin antibody, showing comparable amount of protein in each lane. Bottom panel (b) shows Western blot prepared with SERT antibody 2 on an $8 \%$ minigel using $200 \mu \mathrm{g}$ per lane of total protein preparation from a 5,7-DHT-treated animal (rat) and a SERT-KO mouse. Note marked decrease in abundance of 63$68 \mathrm{kDa}$ band in 5,7-DHT-treated rat and its absence in SERT-KO mouse, both in the parietal cortex (CTX) and midbrain (MB). Also note that the band at approximately $70 \mathrm{kDa}$ is preserved in rat previously lesioned with 5,7-DHT, as well as in SERT-KO mouse. Minor species (rat vs mouse) and regional (cortex vs midbrain) differences are also evident.

examine this issue further and to test the hypothesis that lasting effects of substituted amphetamines might involve neuroadaptive changes in 5-HT metabolism secondary to inactivation or decreased surface expression of the SERT protein, we studied in vivo expression of the SERT protein and other 5-HT neuronal markers (5-HT, 5-HIAA, and TPH) after various substituted amphetamines (MDMA, PCA, FEN), using the established 5-HT neurotoxin, 5,7DHT, as a positive control. Results of Western blot studies indicate that the $70 \mathrm{kDa}$ band previously thought to correspond to the SERT protein (Rothman et al, 2003; Wang et al, 2005) does not exhibit the known relative regional distribution of brain SERT, is resistant to 5,7-DHT treatment, and is present in SERT-KO animals. In contrast, a diffuse band at approximately $63-68 \mathrm{kDa}$ has the expected regional brain distribution of the SERT, is markedly reduced after 5,7-DHT treatment, and is absent in SERTKO animals. Notably, like other 5-HT neuronal indexes, this $63-68 \mathrm{kDa}$ band is reduced 1 week after treatment with

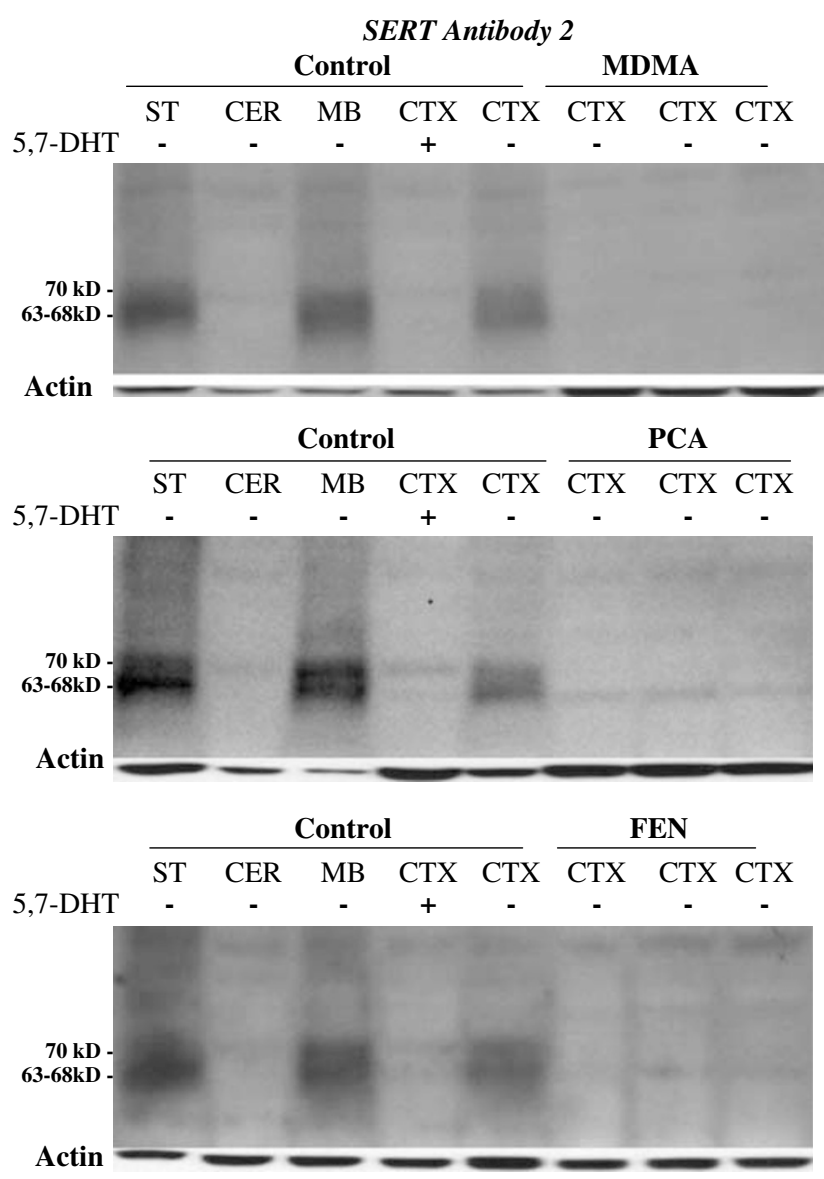

Figure 7 Western blots prepared with SERT antibody 2 showing reduced density of 63-68 kDa band I week after MDMA (top panels), PCA (middle panels), or FEN (bottom panels) treatment. Rats were administered saline or MDMA $(15 \mathrm{mg} / \mathrm{kg}$, orally, every $1.5 \mathrm{~h} \times 3)$, PCA ( $5 \mathrm{mg} / \mathrm{kg}$; i.p.), or FEN $(6 \mathrm{mg} / \mathrm{kg}$ every $2 \mathrm{~h} \times 4$; i.p.) $(n=6-9$ rats in each group). Western blots were prepared on $8 \%$ minigels using a total protein preparation, as described in Materials and Methods. The same PVDF membranes were stripped and reblotted with actin antibody, showing comparable amounts of protein in each lane.

substituted amphetamines (MDMA, PCA, or FEN). These results indicate that SERT protein, as measured by Western blot analysis, is decreased after substituted amphetamines, and that decrements in SERT protein parallel decreases in other 5-HT neuroaxonal markers.

To confirm and extend our Western blot findings, we also studied SERT expression by means of in situ immunocytochemistry (ICC), a complementary approach that allows for visualization of the SERT protein in brain sections. As in the Western blot studies, we used 5,7-DHT as a positive control, and employed the same two SERT antisera (SERT antibodies 1 and 2). After 5,7-DHT treatment, marked reductions in regional brain SERT-IR axon density were evident regardless of which of the two SERT antisera was used. Parallel studies with MDMA (using the same SERT antibodies) yielded similar findings. These results extend findings of the present Western blot analyses and further indicate that substituted amphetamines produce loss of brain SERT protein.

As the SERT protein is a membrane protein that is amenable to changes in surface expression and trafficking 

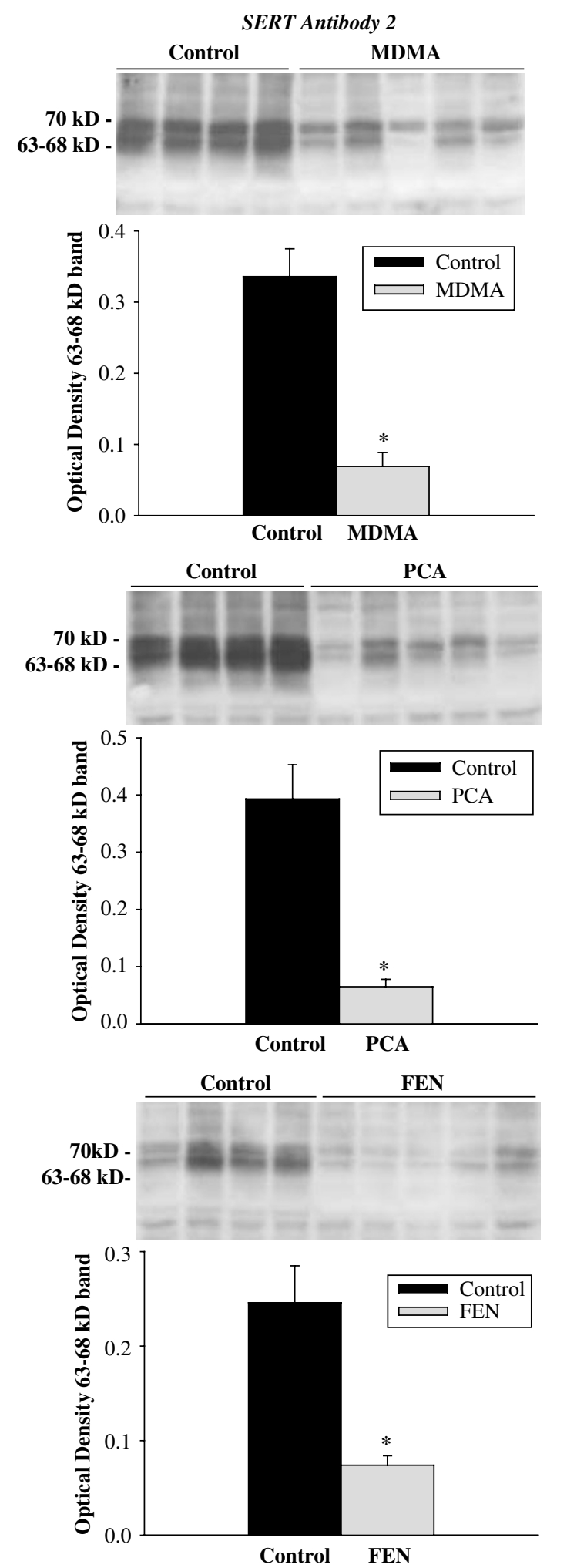

Figure 8 Quantitation of reduced density of 63-68 kDa band I week after treatment with MDMA (top panel), PCA (middle panel), or FEN (bottom panel). Results shown represent the mean \pm SEM for each group. Loading amount was maintained constant at $200 \mu \mathrm{g}$ of protein per lane. In all cases, statistically significant differences represent $p<0.05$; $C=$ control; $\mathrm{E}=$ experimental. *Different from control.
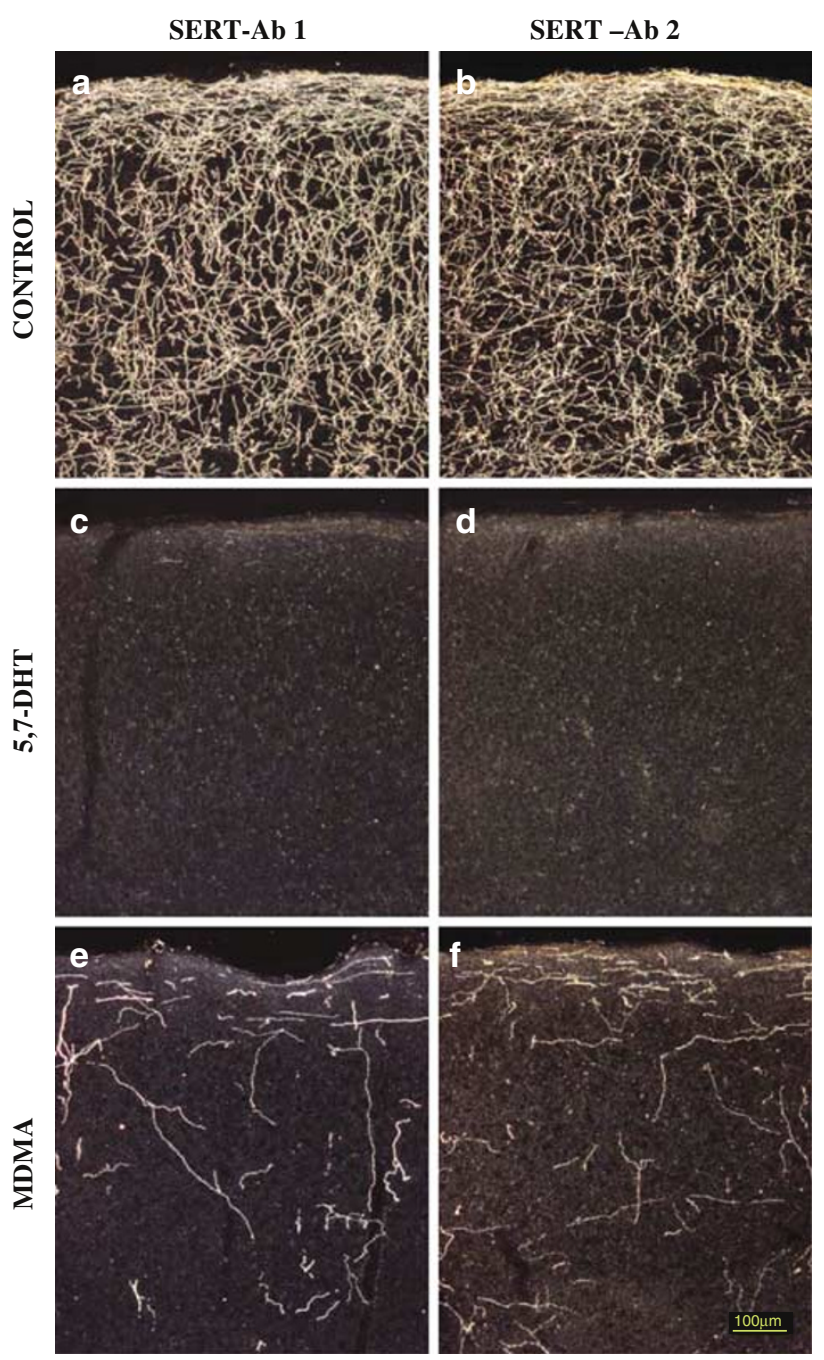

Figure 9 SERT-IR axons visualized with antisera I and antisera 2 in the cerebral (parietal) cortex of representative control rats $(\mathrm{a}, \mathrm{b})$ and rats previously treated with 5,7-DHT (c, d) or MDMA (e, f). Rats received 5,7DHT (i.c.V., $100 \mu g$ ), MDMA ( $15 \mathrm{mg} / \mathrm{kg}$, orally, every $1.5 \mathrm{~h} \times 3$ ), or saline and were killed $1-2$ weeks after drug treatment, as described in Materials and Methods. Compared to controls, note marked reduction in SERT-IR axon density in cerebral cortex of both 5,7-DHT- and MDMA-treated rats.

(see Introduction), we also studied TPH, a cytoplasmic protein that is unique to $5-\mathrm{HT}$ neurons and, to our knowledge, is not modulated by trafficking-dependent pathways. These studies revealed that MDMA, like 5,7DHT, produced reductions in TPH-IR axon density. These results are in agreement with previous biochemical determinations of TPH activity in animals treated with substituted amphetamines (see Gibb et al, 1994), and indicate that cytoplasmic as well as membranous serotonergic proteins are lost after MDMA exposure. In addition, the loss of TPH after MDMA indicates that the profile of lasting serotonergic deficits after substituted amphetamines differs from that in SERT-null animals which have normal TPH levels, but, in the absence of the SERT protein, develop apparent neuroadaptive changes in 5-HT metabolism (Bengel et al, 1998; Kim et al, 2005) (Table 1). Hence, in conjunction with loss of SERT protein, our TPH results mitigate against the notion that decrements in 5-HT and 

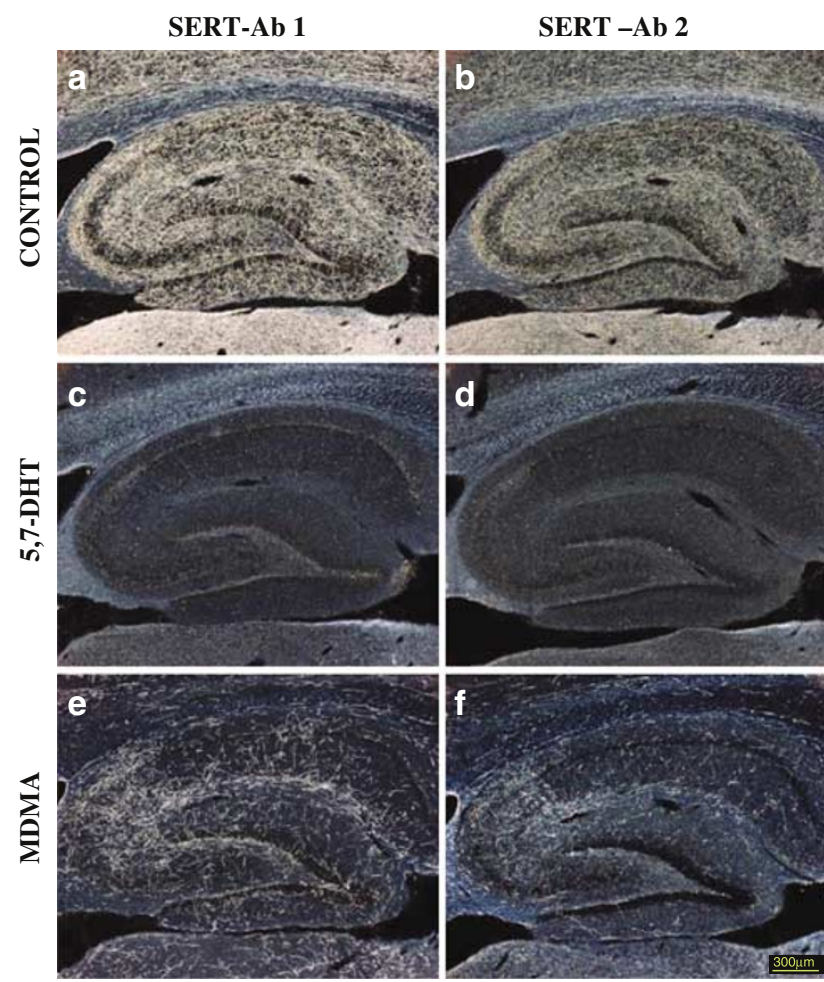

Figure I0 SERT-IR axons visualized with antisera I and antisera 2 in the hippocampal formation of representative control rats $(\mathrm{a}, \mathrm{b})$ and rats previously treated with 5,7-DHT (c, d) or MDMA (e, f). Rats received 5,7DHT (i.c.V., $100 \mu \mathrm{g})$, MDMA $(15 \mathrm{mg} / \mathrm{kg}$, orally, every $1.5 \mathrm{~h} \times 3)$, or saline and were killed I-2 weeks after drug treatment, as described in Materials and Methods. Compared to controls, note marked reduction in SERT-IR axon density in hippocampus of both 5,7-DHT- and MDMA-treated rats.

5-HIAA after substituted amphetamines represent compensatory, neuroadaptive metabolic changes secondary to inactivation or sequestration of membrane SERT protein. Nonetheless, it is possible that residual SERT protein may be subjected to differential SERT trafficking after MDMA, FEN, or PCA administration, resulting in altered 5-HT clearance.

Clearly, reductions in SERT protein, alone or in combination with decreases in other 5-HT neuronal markers, do not, by themselves, constitute conclusive evidence of 5-HT axon terminal destruction. Theoretically, such neurochemical deficits could be secondary to metabolic 'quiescence' of brain 5-HT neurons. While we think this is unlikely, and would maintain, instead, that a neurotoxic effect on serotonergic nerve fibers is the most parsimonious explanation of findings to date, additional data will be required to conclusively demonstrate that lasting effects of substituted amphetamines develop as a consequence of degeneration of 5-HT axon terminals. In this regard, the appearance of highly swollen, distorted, seemingly fragmented axons days after administration of MDMA and related drugs (O'Hearn et al, 1988; Molliver et al, 1990; Sotelo, 1991), along with the development of the 'pruning' phenomenon years after MDMA exposure (Fischer et al, 1995), provide compelling evidence of 5-HT axonal damage. Supporting this view is the fact that virtually identical acute (swollen, distorted axons) and long-term ('pruning') effects have been reported after 5,7-
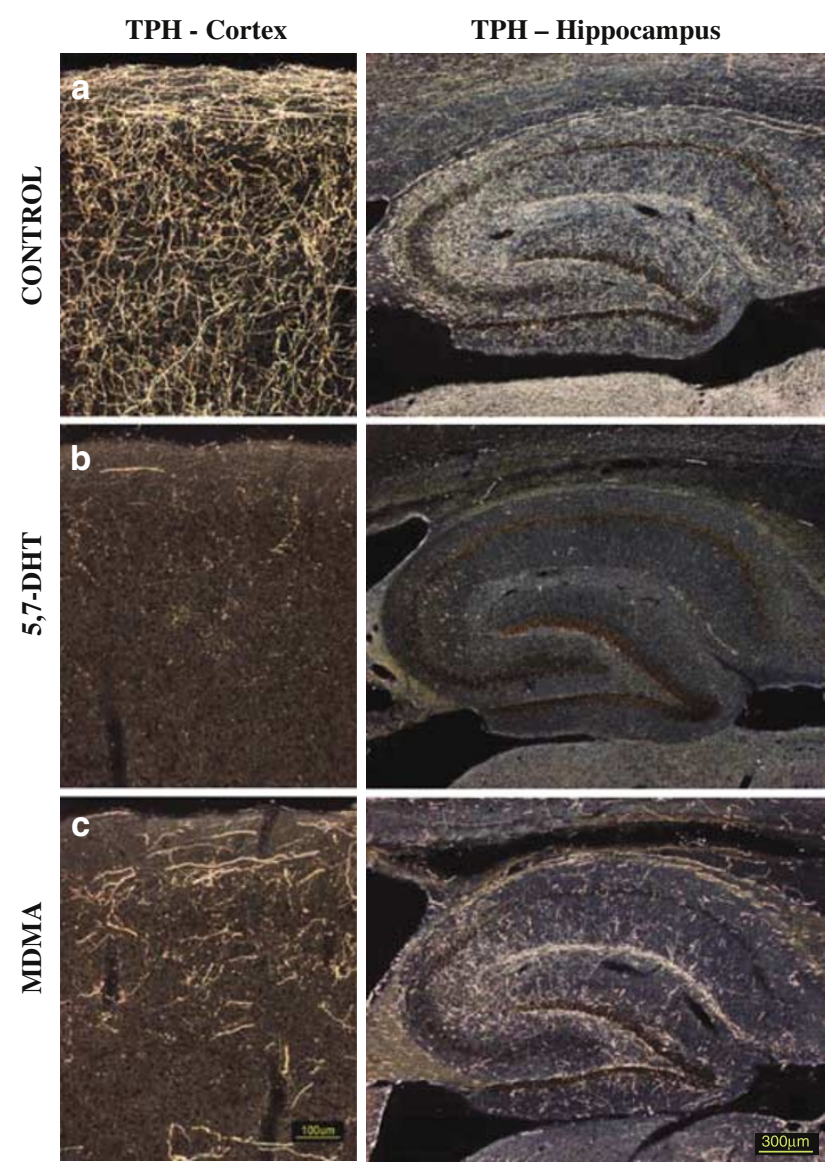

Figure II TPH-IR axons in the cerebral cortex (left panels) and hippocampal formation (right panels) of rats previously treated with 5,7DHT (b) or MDMA (c). Rats received 5,7-DHT (i.c.V., I00 $\mu$ g), MDMA $(\mathrm{I} 5 \mathrm{mg} / \mathrm{kg}$, orally, every I.5 $\mathrm{h} \times 3)$, or saline and were killed I-2 weeks after drug treatment, as described in Materials and Methods. Compared to control (top panels), note marked reduction in TPH-IR axon density in cerebral cortex after 5,7-DHT (middle panels) or MDMA (lower panels) treatments. Also note that the reductions in TPH parallel reductions in SERT shown in Figures 7 and 8.

Table I Changes in Serotonergic Neuronal Markers in SERT-KO Animals and in Animals Previously Treated with MDMA or 5, 7-DHT

\begin{tabular}{lccc}
\hline & SERT-KO & MDMA & 5,7-DHT \\
\hline Neuronal marker & & & \\
SERT & $\Downarrow$ & $\Downarrow$ & $\Downarrow$ \\
[ $^{3}$ H] paroxetine binding & $\Downarrow$ & $\Downarrow$ & $\Downarrow$ \\
5-HT & $\Downarrow$ & $\Downarrow$ & $\Downarrow$ \\
5-HIAA & $\Downarrow$ & $\Downarrow$ & $\Downarrow$ \\
TPH & Normal & $\Downarrow$ & $\Downarrow$ \\
\hline
\end{tabular}

DHT and 5,6-DHT (Bjorklund et al, 1975; Wiklund et al, 1978; Bjorklund and Wiklund, 1980; Jonsson and Hallman, 1982; Jonsson, 1980; Frankfurt and Azmitia, 1984; Frankfurt and Beaudet, 1987), as well as other established monoaminergic neurotoxins treatments (Tomlinson and Bennett, 1979; Jonsson and Hallman, 1982; Jonsson and Sachs, 1982; Fritschy and Grzanna, 1992). 
The previously reported failure to detect a loss of SERT protein in Western blot analyses is not the sole reason why some have questioned the 5-HT neurotoxic potential of substituted amphetamines. In particular, the fact that MDMA and structurally related drugs (PCA, FEN) do not typically produce signs of glial activation in the context of selective 5-HT deficits (Rowland et al, 1993; O'Callaghan and Miller, 1994; Pubill et al, 2003; Wang et al, 2004, 2005; Rothman et al, 2004; Thomas et al, 2004; but see Wilson et al, 1993; Aguirre et al, 1999; Orio et al, 2004) has led some of these investigators to reconsider the notion that substituted amphetamines produce neurotoxic effects. When considering these data, however, it is important to bear in mind that the effects of established 5-HT neurotoxins (5,7-DHT and 5,6-DHT) on glial responses have also been largely negative, particularly in brain regions removed from the site of intracerebral toxin injection (Stagaard et al, 1987; Hardin et al, 1994; Rowland et al, 1993; Bendotti et al, 1994; Dugar et al, 1998; but see Frankfurt et al, 1991; Dugar et al, 1998). Additional research is therefore needed to more fully characterize the determinants, timing, nature, and role of glial responses in the context of selective, chemical lesions limited to fine, relatively sparse brain 5 -HT axon terminals. Such research is likely to provide important insight into the signaling cascade required to prompt glial activation and, as well, a fuller understanding of the role of glia in neurodegenerative processes.

In summary, the present results indicate that selected substituted amphetamines (MDMA, PCA, and FEN), like the classic 5-HT neurotoxin, 5,7-DHT, produce lasting decrements in the SERT protein, as well as other markers of 5-HT axon terminals. Further, in situ immunocytochemical studies show that the loss of the SERT protein is accompanied by a loss of the TPH protein, indicating that lasting serotonergic deficits after substituted amphetamines differ from (presumably) neuroadaptive changes in 5-HT metabolism in SERT-KO animals, which, in the absence of SERT, have markedly reduced concentrations of 5-HT and 5-HIAA, but normal amounts of TPH. Thus, lasting serotonergic deficits after substituted amphetamines are unlikely to represent neuroadaptive metabolic responses to changes in SERT trafficking. Taken together, the available evidence is most compatible with the view that loss of the SERT protein (and other 5-HT neuronal markers) after substituted amphetamines is due to toxic insult rather than neuroadaptation.

\section{ACKNOWLEDGEMENTS}

We thank Dr Fusun Kilic and Dr Richard Rothman for kindly supplying affinity-purified SERT antibodies (see note added in proof). This work was supported by PHS Grants DA13790, DA05707, DA017964, and DA11226.

Note added in proof. We have recently obtained similar results with two other SERT antibodies. The first is directed at amino acid residues $1-15$ of the rat SERT. It is an affinitypurified antibody that was kindly provided by Dr Richard Rothman, and is the same SERT antibody that he and his co-workers used in their most recent publication (Wang et al, 2005). The second, also an affinity-purified SERT antibody, is directed at amino acids 586-630 of the human SERt. It was kindly supplied by Dr Fusun Kilic.

\section{REFERENCES}

Aguirre N, Barrionuevo M, Ramirez MJ, Del Rio J, Lasheras B (1999). Alpha-lipoic acid prevents 3,4-methylenedioxymethamphetamine (MDMA)-induced neurotoxicity. NeuroReport 10: 3675-3680.

Amara S, Kuhar M (1993). Neurotransmitter transporters: recent progress. Annu Rev Neurosci 16: 73-93.

Appel NM, Contrera JF, De Souza EB (1989). Fenfluramine selectively and differentially decreases the density of serotonergic nerve terminals in rat brain: evidence from immunocytochemical studies. J Pharmacol Exp Ther 249: 928-943.

Appel NM, Mitchell WM, Contrera JF, De Souza EB (1990). Effects of high dose fenfluramine treatments on monoamine uptake sites in rat brain: assessment using quantitative autoradiography. Synapse 6: 33-44.

Battaglia G, Yeh SY, O’Hearn E, Molliver ME, Kuhar MJ, Souza EB (1987). 3,4-Methylenedioxymethamphetamine and 3,4-methylenedioxyamphetamine destroy serotonin terminals in rat brain: quantification of neurodegeneration by measurement of $\left[{ }^{3} \mathrm{H}\right]$ paroxetine-labeled serotonin uptake sites. J Pharmacol Exp Ther 242: 911-916.

Baumgarten HG, Lachenmayer L (2004). Serotonin neurotoxins - past and present. Neurotox Res 6: 589-614.

Bendotti C, Baldessari S, Pende M, Tarizzo G, Miari A, Presti ML et al (1994). Does GFAP mRNA and mitochondrial benzodiazepine receptor binding detect serotonergic neuronal degeneration in rat? Brain Res Bull 34: 389-394.

Bengel D, Murphy DL, Andrews AM, Wichems CH, Feltner D, Heils A et al (1998). Altered brain serotonin homeostasis and locomotor insensitivity to 3, 4-methylenedioxymethamphetamine ('Ecstasy') in serotonin transporter-deficient mice. $\mathrm{Mol}$ Pharmacol 53: 649-655.

Bjorklund A, Baumgarten HG, Lachenmayer L, Rosengren E (1975). Recovery of brain noradrenaline after 5,7-dihydroxytryptamine-induced axonal lesions in the rat. Cell Tissue Res 161: 145-155.

Bjorklund A, Wiklund L (1980). Mechanisms of regrowth of the bulbospineal serotonin system following 5,6-dihydroxytryptamine-induced axotomy: biochemical correlates. Brain Res 191: 109-127.

Blakely RD, Berson HE, Fremeau RT, Caron MG, Peek MM, Prince HK et al (1991). Cloning and expression of a functional serotonin transporter from rat brain. Nature 354: 66-70.

Breese GR, Coyle S, Frye GD, Mueller RA (1985). Effects of TRH, ethanol, and TRH-ethanol combination on activity in rats with altered monoamine content. Pharmacol Biochem Behav 22: 1013-1018.

Callahan BT, Cord BJ, Ricaurte GA (2001). Long-term impairment of anterograde axonal transport along fiber projections originating in the rostral raphe nuclei after treatment with fenfluramine or methylenedioxymethamphetamine. Synapse 40: 113-121.

Dugar A, Patanow C, O'Callaghan JP, Lakoski JM (1998). Immunohistochemical localization and quantification of glial fibrillary acidic protein and synaptosomal-associated protein (mol wt 25000) in the ageing hippocampus following administration of 5,7-dihydroxytryptamine. Neuroscience 85: 123-133.

Fischer C, Hatzidimitriou G, Wlos J, Katz J, Ricaurte G (1995). Reorganization of ascending 5-HT axon projections in animals previously exposed to the recreational drug ( \pm ) 3,4-methylenedioxymethamphetamine (MDMA, 'Ecstasy'). J Neurosci 15: 5476-5485. 
Frankfurt M, Azmitia E (1984). Regeneration of serotonergic fibers in the rat hypothalamus following unilateral 5,7-dihydroxytyptamine injection. Brain Res 298: 273-282.

Frankfurt M, Beaudet A (1987). Ultrastructural organization of regenerated serotonin axons in the dorsomedial hypothalamus of the adult rat. J Neurocytol 16: 799-809.

Frankfurt M, O’Callaghan J, Beaudet A (1991). 5,7-Dihydroxytryptamine injections increase glial fibrillary acidic protein in the hypothalamus of adult rats. Brain Res 549: 138-140.

Fritschy J, Grzanna R (1992). Restoration of ascending noradrenergic projections by residual locus coeruleus neurons: compensatory response to neurotoxin-induced cell death in the adult rat brain. J Comp Neurol 321: 421-441.

Fuller RW (1992). Effects of $p$-chloroamphetamine on brain serotonin neurons. Neurochem Res Rev 17: 449-456.

Gerfen CR (1985). The neostriatal mosaic. I. Compartmental organization of projections from the striatum to the substantia nigra in the rat. J Comp Neurol 236: 454-476.

Gibb JW, Hanson GR, Johnson M (1994). Neurochemical mechanisms of toxicity. In: Cho AK, Segal DS (eds). Amphetamine and Its Analogs. Academic Press: San Diego CA. pp 269-295.

Green AR, Mechan AO, Elliott JM, O’Shea E, Colado MI (2003). The pharmacology and clinical pharmacology of 3,4-methylenedioxymethamphetamine (MDMA, 'ecstasy'). Pharmacol Rev 55: 463-508.

Gudelsky GA, Yamamoto BK (2003). Neuropharmacology and neurotoxicity of 3,4-methylenedioxymethamphetamine. Methods Mol Med 79: 55-73.

Hardin H, Bernard A, Rajas F, Fevre-Montange MF, Derrington E, Belin MF et al (1994). Modifications of glial metabolism of glutamate after serotonergic neuron degeneration in the hippocampus of the rat. Mol Brain Res 26: 1-8.

Hatzidimitriou G, McCann UD, Ricaurte GA (1999). Altered serotonin innervation patterns in the forebrain of monkeys treated with 3,4-methylenedioxymethamphetamine seven years previously: factors influencing abnormal recovery. J Neurosci 19: 5096-5107.

Heffner TG, Hartman JA, Seiden LS (1980). A rapid method for the regional dissection of the rat brain. Pharmacol Biochem Behav 13: $453-456$.

Hoffman BJ, Mezey E, Brownstein MJ (1991). Cloning of a serotonin transporter affected by antidepressants. Science 254: $579-580$.

Jonsson G (1980). Chemical neurotoxins as denervation tools in neurobiology. Annu Rev Neurosci 3: 169-187.

Jonsson G, Hallman H (1982). Response of central monoamine neurons following an early neurotoxic lesion. Bibl Anat 1982: 76-92.

Jonsson G, Sachs S (1982). Changes in the development of central noradrenergic neurons after neonatal axonal lesions. Brain Res Bull 9: 641-650.

Kalant H (2001). The pharmacology and toxicology of 'ecstasy' (MDMA) and related drugs. Can Med Assoc J 165: 917-928.

Kim DK, Tolliver TJ, Huang SJ, Martin BJ, Andrews AM, Wichems $\mathrm{C}$ et al (2005). Altered serotonin synthesis, turnover and dynamic regulation in multiple brain regions of mice lacking the serotonin transporter. Neuropharmacology 49: 798-810.

McCann UD, Ricaurte GA (2004). Amphetamine neurotoxicity: accomplishments and remaining challenges. Neurosci Biobehav Rev 27: 821-826.

McCann UD, Seiden LS, Rubin LJ, Ricaurte GA (1997). Brain serotonin neurotoxicity and primary pulmonary hypertension from fenfluramine and dexfenfluramine. A systematic review of the evidence. JAMA 278: 666-672.

Molliver ME, Berger UV, Mamounas LA, Molliver DC, O’Hearn E, Wilson MA (1990). Neurotoxicity of MDMA and related compounds: anatomic studies. Ann N Y Acad Sci 600: 640-664.
O’Callaghan JP, Miller DB (1994). Neurotoxicity profiles of substituted amphetamines in the C57BL/6J mouse. J Pharmacol Exp Ther 270: 741-751.

O'Hearn E, Battaglia G, De Souza EB, Kuhar MJ, Molliver ME (1988). Methylenedioxyamphetamine (MDA) and methylenedioxymethamphetamine (MDMA) cause selective ablation of serotonergic axon terminals in forebrain: immunocytochemical evidence for neurotoxicity. J Neurosci 8: 2788-2803.

Orio L, O'Shea E, Sanchez V, Pradillo JM, Escobedo I, Camarero J et al (2004). 3,4-Methylenedioxymethamphetamine increases interleukin-1beta levels and activates microglia in rat brain: studies on the relationship with acute hyperthermia and 5-HT depletion. J Neurochem 89: 1445-1453.

Paxinos G, Watson C (1998). The Rat Brain in Stereotactic Coordinates, 4th edn. Academic Press: San Diego.

Pubill D, Canudas AM, Pallas M, Camins A, Camarasa J, Escubedo E (2003). Different glial response to methamphetamineand methylenedioxymethamphetamine-induced neurotoxicity. Naunyn Schmiedebergs Arch Pharmacol 367: 490-499.

Qian Y, Galli A, Ramamoorthy S, Risso S, DeFelice LJ, Blakely RD (1997). Protein kinase C activation regulates human serotonin transporters in HEK-293 cells via altered cell surface expression. J Neurosci 17: 45-57.

Qian Y, Melikian HE, Rye DB, Levey AI, Blakely RD (1995). Identification and characterization of antidepressant-sensitive serotonin transporter proteins using site-specific antibodies. J Neurosci 15: 1261-1274.

Quick MW (2003). Regulating the conducting states of a mammalian serotonin transporter. Neuron 40: 537-549.

Ramamoorthy S, Blakely RD (1999). Phosphorylation and sequestration of serotonin transporters differentially modulated by psychostimulants. Science 285: 763-766.

Ricaurte GA, Martello AL, Katz JL, Martello MB (1992). Lasting effects of $( \pm) 3,4$-methylenedioxymethamphetamine (MDMA) on central serotonergic neurons in nonhuman primates: neurochemical observations. J Pharmacol Exp Ther 261: 616-621.

Rothman RB, Jayanthi S, Cadet JL, Wang X, Dersch CM, Baumann MH (2004). Substituted amphetamines that produce long-term serotonin depletion in rat brain ('neurotoxicity') do not decrease serotonin transporter protein expression. Ann N Y Acad Sci 1025: $151-161$.

Rothman RB, Jayanthi S, Wang X, Dersch CM, Cadet JL, Prisinzano $\mathrm{T}$ et al (2003). High-dose fenfluramine administration decreases serotonin transporter binding, but not serotonin transporter protein levels, in rat forebrain. Synapse 50: 233-239.

Rowland NE, Kalehua AN, Li BH, Semple-Rowland SL, Streit WJ (1993). Loss of serotonin uptake sites and immunoreactivity in rat cortex after dexfenfluramine occur without parallel glial cell reaction. Brain Res 624: 35-43.

Rudnick G, Wall SC (1992). The molecular mechanism of 'ecstasy' [3,4-methylenedioxymethamphetamine (MDMA)]: serotonin transporters are targets for MDMA-induced serotonin release. Proc Natl Acad Sci USA 89: 1817-1821.

Samuvel DJ, Jayanthi LD, Bhat NR, Ramamoorthy S (2005). A role for p38 mitogen-activated protein kinase in the regulation of the serotonin transporter: evidence for distinct cellular mechanisms involved in transporter surface expression. $J$ Neurosci 25: 29-41.

Sanders-Bush E, Steranka LR (1978). Immediate and long-term effects of $p$-chloroamphetamine on brain amines. Ann N Y Acad Sci 305: 208-221.

Schuster CR, Lewis M, Seiden LS (1986). Fenfluramine: neurotoxicity. Psychopharmacol Bul 22: 148-151.

Seiden LS, Sabol KE (1996). Methamphetamine and methylenedioxymethamphetamine neurotoxicity: possible mechanisms of cell destruction. NIDA Res Monogr 163: 251-276. 
Sotelo C (1991). Immunohistochemical study of short- and long-term effects of DL-fenfluramine on the serotonergic innervation of the rat hippocampal formation. Brain Res 1541: 309-326.

Stagaard M, Balslev Y, Lundberg JJ, Mollgard K (1987). Microglia in the hypendyma of the rat subcommissural organ following brain lesion with serotonin neurotoxin. J Neurocytol 16: 131-142.

Tate CG, Blakely RD (1994). The effect of N-linked glycosylation on activity of the $\mathrm{Na}(+)-$ and $\mathrm{Cl}(-)$-dependent serotonin transporter expressed using recombinant baculovirus in insect cells. J Biol Chem 269: 26303-26310.

Thomas DM, Dowgiert J, Geddes TJ, Francescutti-Verbeem D, Liu X, Kuhn DM (2004). Microglial activation is a pharmacologically specific marker for the neurotoxic amphetamines. Neurosci Lett 367: 349-354.

Tomlinson DR, Bennett T (1979). Fluorescence histochemical and ultrastructural observations on preterminal noradrenergic axons following ligation or treatment with 6-hydroxydopamine. Med Biol 57: 39-47.
Wang X, Baumann MH, Xu H, Morales M, Rothman RB (2005). 3,4-Methylenedioxymethamphetamine (MDMA) administration to rats does not decrease levels of the serotonin transporter protein or alter its distribution between endosomes and the plasma membrane. J Pharmacol Exp Ther 314: 1002-1012.

Wang X, Baumann MH, Xu H, Rothman RB (2004). 3,4methylenedioxymethamphetamine (MDMA) administration to rats decreases brain tissue serotonin but not serotonin transporter protein and glial fibrillary acidic protein. Synapse 53: $240-248$

Whitworth TL, Herndon LC, Quick MW (2002). Psychostimulants differentially regulate serotonin transporter expression in thalamocortical neurons. J Neurosci 22: RC192.

Wiklund L, Bjorklund A, Nobin A (1978). Regeneration of serotonin neurons in the rat brain after 5,6-dihydroxytryptamine-induced axotomy. Ann NY Acad Sci 305: 370-384.

Wilson MA, Mamounas LA, Fasman KH, Axt KJ, Molliver ME (1993). Reactions of 5-HT neurons to drugs of abuse: neurotoxicity and plasticity. NIDA Res Monogr 136: 155-178. 